\title{
CAMPAIGN MASK FACTORY TO COMBAT THE COVID-19 PANDEMIC AND THE SEWERS' WORK: CONTEXT AND CHALLENGES FOR ACTION OF SENAI MATO GROSSO
}

Denise Torres Molina, Layla Leão Lima Teixeira, Lélia Rocha Abadio Brun, Camila de Sousa Pereira-Guizzo ${ }^{a}$

a Graduate Program in Management and Industrial Technology, SENAI CIMATEC University Center, Brazil

\begin{abstract}
In 2020, the Coronavirus Pandemic triggered a mobilization all over the world for the manufacturing of face masks as a piece of personal protection equipment (PPE) for daily use. The objective of this paper was to discuss the context of the implementation of a campaign mask factory to combat the COVID-19 of SENAI Mato Grosso and the challenges related to the work demands and resources for the sewers. For that, a documentary analysis of institutional materials was carried out. The main results point to the context of coping with the crisis (the pandemic), in which the main challenge is to promote the necessary resources to ensure the motivation and the handing of the demands of the sewers to an elevated process of production.
\end{abstract}

Keywords: demands and resources; sewers; mask factory.

\section{FÁBRICA DE CAMPANHA DE MÁSCARA PARA O ENFRENTAMENTO DA PANDEMIA DE COVID-19 E O TRABALHO DAS COSTUREIRAS: CONTEXTO E DESAFIOS PARA A AÇÃO DO SENAI MATO GROSSO}

Resumo: O Coronavírus desencadeou em toda a população mundial, em 2020, uma mobilização relevante no que se refere à fabricação de máscaras como equipamentos de proteção individual (EPI) para uso diário. Este artigo teve como objetivo discutir o contexto de implantação de uma fábrica de campanha de máscaras para enfrentamento de COVID-19 do SENAI Mato Grosso e os desafios relacionados às demandas e aos recursos do trabalho dessas costureiras. Para isso, foi realizada uma análise documental de materiais institucionais. Os principais resultados apontam um contexto de enfrentamento de crise (pandemia), no qual o principal desafio é promover recursos necessários para assegurar a motivação e o manejo das demandas dessas costureiras para um processo elevado de produção.

Palavras-chave: demanda e recursos; costureiras; fábrica de máscaras.

\section{INTRODUCTION}

Coronavirus is a family of viruses, observed in humans in 1937, identified only in 1965, and which now shows itself with a new variant - coronavirus 2 (SARS-CoV2). SARS-CoV-2 was registered in humans in 12/31/2019, in Wuhan, Hubei province 
in China, which causes a disease called COVID-19, gaining pandemic coverage in March of 2020 [1].

This pandemic has triggered a significant mobilization in the entire world population concerning the manufacture of personal protection equipment (PPE) for daily use, especially the manufacturing of masks. Previously indicated as a tool of mandatory use by health workers in the workplace, it is now extended to the entire population [1]. At the same speed, as it appeared, this disease spread throughout the world, disrupting the existing masks manufacturing bases, leading to countless factories that make up the textile chain to adjust their production processes for the production of this PPE. The role of seamstresses in this process of fighting COVID-19 proved to be relevant since these are the main suppliers to the clothing industry.

The search process for sewing professionals generated in the entire workgroup involved in the implantation of the SENAI Mato Grosso (MT) mask campaign factory an initial perception that it would be easy, after all, the operational unit had already trained so many professionals in this area. However, it was not observed. In the group of candidate seamstresses, there was a marked number of people with low education, a prominence of several physicals, emotional, and social disabilities, in addition to a lack of basic survival resources. Finding and motivating these professionals to produce this PPE proved to be a challenge.

Engagement at work can arise in activities that have a relevant purpose for the worker, resulting in increased performance, as there is an investment of effort, energy, and dedication in a context of balance between demands and work resources [2]. In this concept, resources are understood as a set of physical, psychological, social, or organizational aspects that soften the demand; and demands also correspond to physical, psychological, social, or organizational aspects, which require effort from the person [3]. The demands are not always negative, only when they require skills that the individual does not have, which implies being attentive to the activity of the workers to motivate them towards the goals, but without harming the physical or mental health of these professionals [2,3].

Considering the various implications of the pandemic on people's lives and the importance of prevention actions, the objective of this paper was to discuss the context of implantation of a campaign mask factory to face COVID-19 from SENAI MT and the challenges related to demands and resources of the seamstresses' work.

\section{METHODOLOGY}

The documental research raises unedited or untreated scientifically material. For example, letters, memos, personal correspondence, newspaper reports, recordings and other promotional materials. The use of documents to the research brings a richness of information, since they can be used in several areas, approaching the understanding of the object in its historical and socio-cultural context [11].

For this study, documentary analysis of institutional materials, radio interviews, local newspapers, and literature reviews were applied. These materials were collected and analyzed from April to July 2020.The results are presented in a narrative way, allowing to report the context and the challenges. 
The campaign masks factory was structured in the school unit of the National Service of Industrial Learning of the State of Mato Grosso (SENAI MT), located in the city of Cuiabá / MT. In partnership with the State Department of Health, this campaign factory is expected to operate from April to October 2020. In the physical space, 100 units of straight-line sewing machines were installed, positioned at a distance of two meters between the other machines, arranged in front and on the sides, according to safety rules established by the World Health Organization for COVID-19 [1].

Mass dissemination was carried out in the media to search for seamstresses interested in participating in this project. At first, 200 seamstresses were registered. These were selected and inserted into the production process. The most motivated and interested ones remained in the process, while some demonstrated the need to discontinue their activities, for various reasons. Currently, around 100 seamstresses work in the field factory through a service contract. The masks production process takes place in three six-hour shifts (morning, afternoon, and evening), and can be carried out according to the interest of each seamstress.

The first stage of the production process included the training of seamstresses in the manufacture of the model of masks established for the project. These models were previously evaluated and validated by the partner, the Health Department of the State of Mato Grosso. After training, the seamstresses continue with the confection itself and, at all times, are assisted by professors in the clothing area, who in addition to assessing the quality of production, insert the necessary guidelines through technical mentoring (guidance). There is also assistance in implementing a leaner production methodology (Lean Manufacturing).

The production process used was established on the spot according to tools provided for in the Lean Manufacturing methodology, which advocates adding value to the product, from the customer's perspective, through the use of waste reduction strategies, such as stock, defects, waiting time, transportation of materials and products, excessive production and skills [4]. This methodology was adopted for modeling straight seam masks, with three layers, made of non - woven fabric (TNT).

The mask campaign factory is composed of a set of actions and / or actors from different Operational Units of SENAI MT. The Regional Department of SENAI MT with management and people suppport, the SENAI Unit of the Industrial District with people support, the Unit of the SENAI Institute of Technology with people, and the SENAI Unit of Rondonópolis with spare machines. This group is managed by the team from SENAI Regional Departament (MT) and Senai Cuiabá (MT). These actors range from regional directors, management, coordinators, and teachers of professional education, as well as technicians and consultants in technology and innovation. The masks made are intended for the Health Department of the State of Mato Grosso, which, in turn, sterilizes them and is intended for use by health professionals in hospitals in the State of Mato Grosso.

\section{RESULTS AND DISCUSSION}

In the process of searching for seamstresses to collaborate in the mask campaign factory, many women appeared with serious problems in their homes, with unstructured families and without basic food resources. Also, men with difficulties to support their homes were willing to join this group of workers, previously mostly 
composed of women. In addition to the many shortcomings, the pandemic process presented itself as a novelty, repositioning not only companies but the entire population to understand how to perform basic and routine tasks of life in society.

Sewing work has some important particularities that must be considered when managing people. In a recent study [7], the authors analyzed memories and stories of women who structured their lives from the seamstress profession. The autobiographical narratives report that the seamstress relates to her craft, lives, and experiences every moment, seeking to balance both the work environment - in which she needs to take care of her seams, take customer measurements, cut and sew fabrics, try on clothes on the body of those who ordered them, make adjustments, when necessary, and finally deliver the goods properly ironed - but also assuming the incessant task of taking care of the home and family, in addition to tidying up domestic environments, preparing the family food, personal hygiene of children, washing and ironing their clothes, teaching them to read and helping with homework, taking care of school pick-up and drop-off times, inventing and telling stories, putting to sleep and waking up, among others.

Among the different demands related to the work of seamstresses, physical strain due to hours on a sewing machine is constantly encountered. In a survey [8], the authors analyzed factors that can minimize the impacts of sitting posture in the work of dressmakers in the clothing industry, suggesting: the increase in the number of breaks, with shorter times; the exchange of existing chairs for chairs that have a height compatible with the height of the worker, which is swiveling, eliminating effort in the spine, due to continuous lateral movements; upholstered in material that does not deform, reducing the possibility of compression of the lower limbs; adjustable backrest to adapt to the worker's body, protecting the lower back and avoiding protrusion of the head, which reduces pain in the cervical region; production of machines in which the worker could alternate between sitting and standing sewing.

In another survey [9], it was possible to identify the determining factors for the motivation of the employees of the Union of Officers Tailors, Seamstresses, and Workers in the clothing manufacturing industry in the state of Rio Grande do Norte. In the investigation, it was found that there are positive factors such as proper working conditions, work itself, relationships with colleagues, salary, and the services that the organization provides to the target audience. However, the main negative factor identified in the study was the manager's relationship with employees.

Although there are many physical, social, and psychological demands associated with the work of seamstresses, it is noted that the social support provided by the relationship at work can be a very positive resource. Specifically, in the manufacture of masking campaigns, the interaction with the seamstresses allowed us to note that many are involved in the factory's work not only because of the need for subsistence and/or aggregation of income but for the social impact that this generates in their lives and the opportunity to do part of a project that will benefit other people, especially health professionals - doctors, nurses, among others. According to a seamstress' report "With much love and dedication, I protect you so that you can protect other lives" [6]. Additionally, she reinforces another seamstress "I have already made costumes, dresses, pants, and even clothes for those who have died. But the mask I had never done. Today we all have to use it, it is neither rich nor poor, we all have to protect ourselves from this disease "[6]. This analysis is in line with other 
studies [7,9] that signaled similar factors (the meaning of work, relationship with colleagues, and the type of service provided) for the motivation of seamstresses.

This experience at the masks campaign factory has also had a positive impact on the life plan of many seamstresses. Some of these seamstresses are experiencing this professionally for the first time and want to remain in this craft. Many seamstresses who entered the morning shift were those who stayed for all shifts. Most have already shown interest in the SENAI courses corresponding to the clothing area.

It is also noted that the mask campaign factory has generated a collaborative environment. As time goes by, the seamstresses themselves help each other, training each other in quality and productiveness assurance, as the report shows "I arrived with two crutches, sat on the machine, and with the help of the team I managed to produce. On the first day I did 47 and today I do 150 in part-time. Here we are saving lives and helping those in need" [6]. As the majority belongs to a social class of many needs, in addition to personal difficulties, in many situations the seamstresses help each other, making up an ecosystem of assistance and cooperativism.

Many seamstresses report improvements in physical and emotional health made possible by the experience in the campaign factory and with the income obtained. Some reports, cited in institutional material, reinforce the involvement and motivation of these seamstresses with the work in the campaign factory to face the pandemic: "Value matters, but even more important is to have a place to go every day when you wake up. It is a happy, happy space. Leaving home early happy for your job is for a few, right? This is because if you are doing what you like, you are helping and, still, you are getting paid." [6].

The field factory recently surpassed the production of two million masks. Some seamstresses produce more than nine thousand masks a month and receive up to $\mathrm{R} \$$ $3,545.40[5,6]$. The recent report by the president of the Federation of Industries System in the State of Mato Grosso portrays the context of the mask campaign factory to face the pandemic: "Two million is a significant number and represents the effort that the industry has to help our state. It is a deep and complex crisis that affects all people and economic sectors from different aspects" [6]. This context poses numerous challenges for society in general and for the productive and professional sectors involved in projects directly related to facing the pandemic.

Thus, it is clear that the physical resources related to the production structure (equipment, room, lighting, sewing machines), the resources related to the management of these seamstresses (relationship with supervision), the resources related to social support among the companies themselves. Seamstresses, in addition to the significance of this work at the campaign factory, are collaborating so that they can deal with the high demands of production and facing the pandemic. The balance between demands and resources in production is an important point in the work process, with positive implications for workers and companies. Achieving this balance in a challenging context, such as the COVID-19 pandemic, is becoming even more challenging, requiring the commitment and motivation of everyone involved. Although organizations currently experience a work environment where technology and people interact daily, it is in the ability to engage workers that they can become most successful [10]. 


\section{CONCLUSION}

It is concluded that the main challenge of the pandemic campaign factory is to establish the necessary resources to ensure the motivation and the management of the demands of these seamstresses for a production process, in which the requirement of meeting high levels of production prevails, due to the need for an emergency supply of an input. The main results point to the positive implications of work at the mask campaign factory for the personal and professional lives of these seamstresses, suggesting that the resources offered are collaborating to meet the demands and the motivation of these professionals. Faced with this pandemic scenario and consistent with the context and challenges of the SENAI MT campaign mask factory, future research is sought to deepen the understanding of engagement at work and the production of seamstresses.

\section{REFERENCES}

${ }^{1}$ MINISTRY OF HEALTH, Technical Report of the Secretariat of Primary Health Care, Brasília, 2020. Available at https://coronavirus.saude.gov.br/sobre-a-doenca\#oque-e-covid. Accessed on 19/04/2020.

${ }^{2}$ VAZQUEZ, A. C. S. et al. Evaluation of people's engagement with their work: The Brazilian version of the Utrecht Scale for Engagement at Work (UWES). In C. S. HUTZ (Orgs). Evaluation of positive psychology - techniques and measures. Porto Alegre: Artmed, p.75-89. 2016.

${ }^{3}$ SCHAUFELI, W., BAKKER, A. B., VAN RHENEN, W. How changes in job demands and resources predict burnout, work engagement, and sickness absenteeism. Journal of Organizational Behavior, v. 30, n. 7, p. 893-917, 2009.

${ }^{4}$ IKEZIRI, L. M., MELO, J. C., CAMPOS, R. T., OKIMURA, L. I., JUNIOR, J. A. G. The industry 4.0 Perspective on Lean Manufacturing Management Philosophy. Braz. J. of Develop, Curitiba, v. 6, n. 1,p.1274- 1289. 2020. ISSN 2525-8761.

${ }^{5}$ FIRST PAGE PROGRAM, Rádio Centro América FM 101, Senai MT Reaches 2 Million Masks Produced to Prevent Covid-19, Rondonópolis, 2020. Available at http://c.eficazro.com.br/fiemt/personalizacao/fiemt/ noticia / noticia.asp? cd_noticia = 77849957. Accessed 19/07/2020.

6 NATIONAL INDUSTRIAL LEARNING SERVICE IN THE STATE OF MATO GROSSO, Notícias, SENAI MT Reaches 2 Million Masks Produced, Cuiabá, 2020. Available at https://www.senaimt.ind.br/noticias/1835/senai-mt-atinge -2-millionmasks-produced. Accessed 19/07/2020. 
${ }^{7}$ PASSOS, M. C. P., PEREIRA, R. M. R., SILVA, V. O. S. Seamstresses: Aligning Stories and Memories, Brazilian Journal of (Auto) Biographical Research, Salvador, v. 04, n. 12, p. 1155-1167, 2019.

${ }^{8}$ AMBROSI, D., QUEIROZ, M. F. F., Understanding Sewing Work: An Approach to Sitting Posture. Brazilian Journal of Occupational Health, São Paulo, v. 29 , n. 109, p. 11-19, 2004.

${ }^{9}$ FELIPE, J. L. C. Motivation Factors of Employees of the Union of Tailors, Seamstresses and Workers in the Clothing Industry in the State of Rio Grande do Norte. Monograph - Administration, Federal University of Rio Grande do Norte. Christmas, 2017.

${ }^{10}$ PUGLIANO, J. The Arrival of Robots: A Survival Guide for Human Beings to Benefit in the Era of Automation. 1st ed. São Paulo: Madras. 2017.

${ }^{11}$ CECHINEL, A.; FONTANA, S. A. P.; DELLA, K. G. P.; PEREIRA, A. S.; PRADO, S. $S$. Estudo/análise documental: uma revisão teórica e metodológica. Criar Educação, v. 5, n. 1, p. 1-7, 2016. 